\title{
Changes in cardiopulmonary
}

\section{response to exercise after cardiac transplantation in patients enrolled in an early rehabilitation program}

\author{
LizANNe M Bussières Md PhD, Peter W Pflugfelder md, Albert W TAYlor PhD, \\ DILDAR AHMAD MD, CORINNE WEERNINK, WILLIAM J KOSTUK MD \\ Faculty of Kinesiology; Divisions of Cardiology, Respiratory Medicine and Physiotherapy, \\ Department of Medicine, The University of Western Ontario; and University Hospital, \\ London, Ontario
}

LM Bussières, PW Pflugfelder, AW Taylor, D Ahmad, C Weernink, WJ Kostuk. Changes in the cardiopulmonary response to exercise after cardiac transplantation in patients enrolled in an early rehabilitation program. Can Respir J 1997;4(2):81-87.

OBJECTIVE: To evaluate the changes in the cardiopulmonary response to exercise in the first year after cardiac transplantation in patients enrolled in a rehabilitation program in the first three months post-transplantation.

METHODS: A graded cycle exercise test with mixed expired gas analysis was performed on patients with end-stage cardiac failure before and serially after cardiac transplantation at one, three and 12 months.

RESULTS: Before cardiac transplantation, seven patients were fit enough to be tested. They had a low peak oxygen uptake ( $\dot{\mathrm{VO}}_{2} \max$ ) and a blunted heart rate and blood pressure response to exercise. They also displayed a restrictive pattern of ventilation during exercise. At three months following transplantation, patients $(n=19)$ had a significantly higher $\mathrm{VO}_{2} \max (19.9 \pm 5.3$ versus $9.8 \pm 1.4 \mathrm{~mL} / \mathrm{kg} / \mathrm{min}$, $\mathrm{P}<0.05)$, higher peak systolic blood pressure $(177 \pm 22$ versus $94 \pm 18 \mathrm{mmHg}, \mathrm{P}<0.05)$, greater peak minute ventilation (70 \pm 23 versus $34 \pm 5 \mathrm{~L} / \mathrm{min}, \mathrm{P}<0.05$ ) and lower slope of minute ventilation to carbon dioxide output $(35.4 \pm 6.2$ versus $45.1 \pm 6.7, \mathrm{P}<0.05)$ than before transplantation. The $\mathrm{VO}_{2}$ max measured at 12 months post-transplant was similar to the three month value and was on average equal to $59 \%$ of the predicted value.

CONCLUSIONS: These results indicate that there is a rapid and marked improvement in exercise capacity in patients following cardiac transplantation. These changes are associated with significant respiratory and cardiovascular adaptations. However, despite the marked improvement in exercise capacity, the $\mathrm{VO}_{2}$ max of cardiac transplant recipients enrolled in an early rehabilitation program did not return to normal at 12 months after surgery.

Key Words: Exercise capacity, Exercise training, Heart failure, Heart transplantation

Changements dans la réponse cardiopulmonaire à l'exercice après une transplantation cardiaque chez des patients inclus dans un programme de réadaptation

OBJECTIFS : Évaluer les changements dans la réponse cardiopulmonaire à l'exercice dans la première année faisant suite à une transplantation cardiaque chez des patients inclus dans un programme de réadaptation dans les trois premiers mois posttransplantation.

MÉTHODES : Une épreuve d'exercice graduée sur bicyclette associée à une analyse des gaz expirés a été pratiquée chez des patients atteints d'une insuffisance cardiaque terminale, avant et en série après une transplantation cardiaque, à un, trois et douze mois.

voir page suivante

Correspondence and reprints: Dr Lizanne M Bussières, Research Centre, Montreal Heart Institute, 5000 Belanger Street East, Montreal, Quebec H1T 1C8. Telephone 514-374-1480, fax 514-374-2416 
RÉSULTATS : Avant de subir une transplantation cardiaque, 7 patients ont pu réaliser le test. On a pu observer une consommation maximale d'oxygène ( $\mathrm{VO}_{2}$ max $)$ basse et une réponse amoindrie du rythme cardiaque et de la pression sanguine à l'exercice. Les patients présentaient également un schéma restrictif de la ventilation pendant l'exercice. Trois mois après la transplạntation, les patients $(n=19)$ avaient sensiblement amélioré leur $\mathrm{VO}_{2} \max$ $(19,9 \pm 5,3$ contre $9,8 \pm 1,4 \mathrm{ml} / \mathrm{kg} / \mathrm{min}, \mathrm{P}<0,05)$, la pression sanguine systolique maximale $(177 \pm 22$ contre $94 \pm 18 \mathrm{mmHg}$, $\mathrm{P}<0,05)$, la ventilation minute maximale $(70 \pm 23$ contre $34 \pm 5$ $\mathrm{L} / \mathrm{mn}, \mathrm{P}<0,05)$. La pente du graphique de la ventilation minute par rapport au débit du gaz carbonique expiré était diminuée
$(35,4 \pm 6,2$ avant contre $45,1 \pm 6,7$ apres la transplantation, $\mathrm{P}<0,05)$. La $\mathrm{VO}_{2}$ max mesurée 12 mois après la transplantation était comparable à la valeur obtenue à 3 mois et était en moyenne égale à 59 $\%$ de la valeur prédite.

CONCLUSIONS : Ces résultats démontrent que la capacité d'exercice augmente rapidement et sensiblement chez les patients qui ont subi une transplantation cardiaque. Ces changements sont associés à des adaptations importantes des systèmes cardiovasculaire et respiratoire. Cependant, malgré l'amélioration sensible de la capacité d'exercice, la $\mathrm{VO}_{2}$ max des transplantés cardiaques inclus dans un programme de rééducation n'était pas revenue à la normale 12 mois après la chirurgie.
$\mathrm{F}$ ew interventions for end-stage heart failure so dramatically improve exercise capacity than cardiac transplantation, now a well-established therapy for end-stage heart disease (1). In patients with severe cardiac failure, hypoperfusion of working muscle and pulmonary congestion lead to early fatigue and exertional dyspnea, which limit exercise capacity (2). While all patients selected for cardiac transplantation have end-stage cardiac failure with New York Heart Association functional class III or IV disability, more than $95 \%$ of those who survive one year return to functional class I status (1). The time course and magnitude of the improvement in exercise capacity and the associated changes in the cardiovascular and pulmonary response to exercise have not been well described.

In the present study, we have investigated the changes in peak oxygen uptake and cardiopulmonary response to exercise in the first 12 months after cardiac transplantation in patients enrolled in an early rehabilitation program.

\section{PATIENTS AND METHODS}

Patient population: This study received approval from the Review Board for Health Sciences Research Involving Human Subjects of The University of Western Ontario, London, Ontario, and all subjects gave informed consent upon study entry. Nineteen consecutive patients (one female and 18 males) who underwent successful cardiac transplantation and survived the first postoperative year were included in the study. Mean age at the time of transplantation of the patients was $46 \pm 9$ years of age (range 27 to 60 ). All patients were in New York Heart Association functional class III or IV before transplantation. The etiology of end-stage heart failure was coronary artery disease in eight patients, cardiomyopathy in 10 and valvular heart disease in one. While awaiting cardiac transplantation, all patients were treated with an optimal antifailure regimen that included diuretics, angiotensin-converting enzyme inhibitors and digoxin. After transplantation, the immunosuppressive regimen consisted of prednisone and cyclosporine to which azathioprine was added within one month in three patients, within three months in five and within 12 months in seven. The average dose of prednisone was $20 \pm 1 \mathrm{mg}, 18 \pm 1 \mathrm{mg}$ and $7 \pm 1 \mathrm{mg}$ at one, three and 12 months, respectively. The average daily dose of cyclosporin was $600 \mathrm{mg}, 450 \mathrm{mg}$ and $350 \mathrm{mg}$, respectively. Other medications in the postoperative period included diuretics (in seven patients at one month, four at three months and four at 12 months), calcium channel blockers (in two patients at one month, four at three months, and eight at 12 months) and angiotensin-converting enzyme inhibitors (in one patient at one and three months, and two patients at 12 months).

Rehabilitation program: At our centre, all patients are enrolled in an in-hospital physical rehabilitation program for the first three months following cardiac transplantation. This is possible because patients from out of town stay at nearby facilities for the first three months after transplantation. In this study, all patients participated in the exercise program. The program began with rapid mobilization and exercises in the first operative week. Thereafter, and for up to three months, a more structured exercise program (five mornings per week) was conducted. The exercise regimen consisted of 60 mins of supervised stationary cycling, treadmill exercise, stair climbing, upper and lower extremity strengthening, as well as stretching exercises. Exercise duration and intensity of the cycle and treadmill exercise increased with patient recovery. On average, patients cycled or walked on the treadmill on alternating days for 20 mins at six weeks after transplantation. The intensity was designed to elicit perceived exertion rating of "somewhat hard" (modified Borg scale 4 to 6). After three months, there was no organized rehabilitation program. Patients were encouraged to maintain fitness and received instructions and personal recommendations to continue exercise training at home; only three patients, however, exercised regularly for 30 mins at least three times a week at 12 months post-transplant.

Cardiopulmonary exercise testing: Before transplant seven of the 19 patients underwent an exercise test after being accepted for cardiac transplant. After transplant, one patient did not undergo exercise testing at one and three months because of Pneumocystis carinii pneumonia. Another patient was not tested at one month because of a leaking lymphocele in the femoral area, a complication from an intra-aortic balloon inserted at the time of transplant. No patient had acute rejection at the time of the exercise testing. Antihypertensive medications were withheld on the morning of the exercise test. The exercise test consisted of symptom-limited upright graded exercise on a cycle ergometer. The initial workload was 12.5 or 25 Watts and the workload was increased by 12.5 or 25 Watts every 3 mins depending on the patient's ability to exercise. Blood pressure was taken by sphygmomanome- 
Resting supine hemodynamics before and after cardiac transplantation (mean \pm SD)

\begin{tabular}{|c|c|c|c|c|}
\hline & $\begin{array}{l}\text { Before transplant } \\
(n=19)\end{array}$ & One to two weeks $(n=18)$ & $\begin{array}{l}\text { After transplant } \\
\text { Three months }(n=19)\end{array}$ & 12 months $(n=19)$ \\
\hline Right atrial pressure $(\mathrm{mmHg})$ & $13 \pm 7$ & $8 \pm 4^{*}$ & $6 \pm 3^{*}$ & $5 \pm 3^{*}$ \\
\hline $\begin{array}{l}\text { Pulmonary capillary wedge pressure } \\
(\mathrm{mmHg})\end{array}$ & $23 \pm 8$ & $14 \pm 6^{*}$ & $12 \pm 4^{*}$ & $13 \pm 7^{*}$ \\
\hline Cardiac index $\left(\mathrm{L} / \mathrm{min} / \mathrm{m}^{2}\right)$ & $1.9 \pm 0.6$ & $3.0 \pm 0.6^{*}$ & $3.0 \pm 0.5^{*}$ & $3.3 \pm 0.5^{\star}$ \\
\hline
\end{tabular}

TABLE 2

Cardiopulmonary exercise test results before and after cardiac transplantation (mean \pm SD)

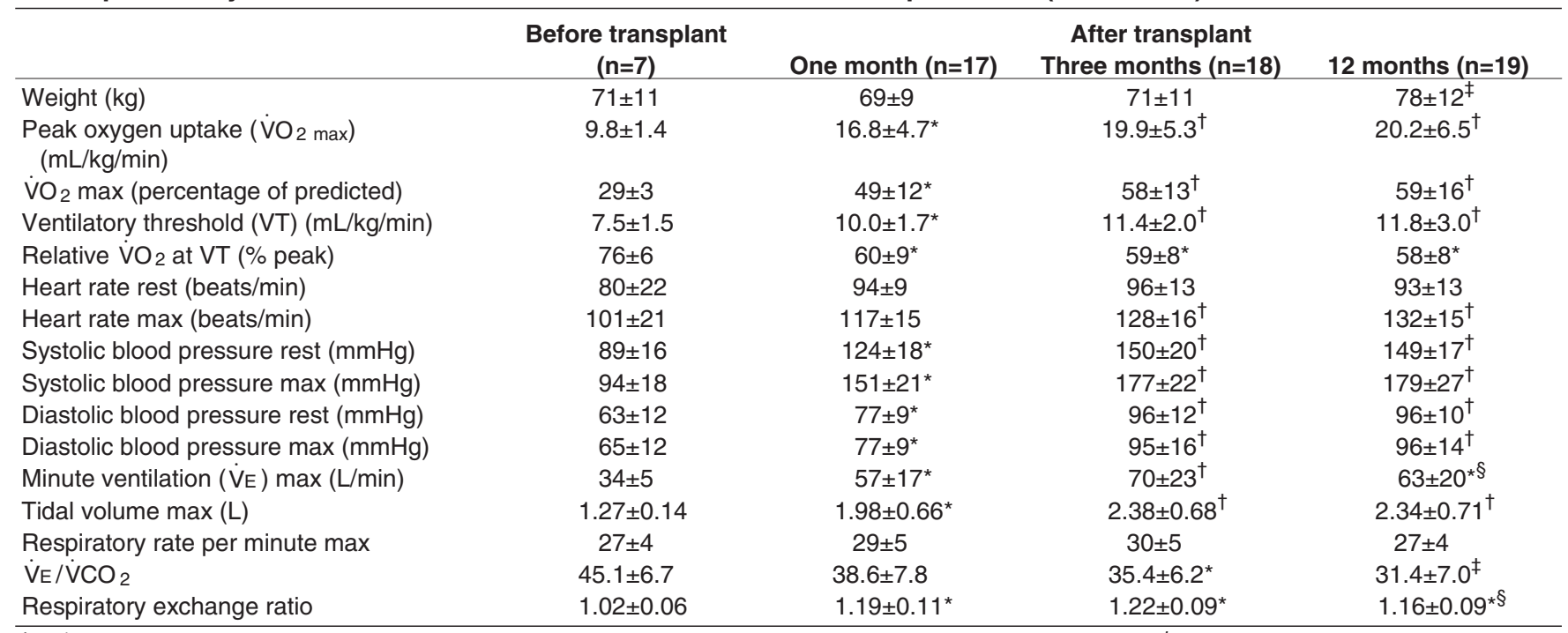

$\dot{\mathrm{V}}_{\mathrm{E}} \dot{\mathrm{V}} \mathrm{CO}_{2}$ Relation between minute ventilation and carbon dioxide output. ${ }^{*} P<0.05$ versus before transplant; ${ }^{\dagger} P<0.05$ versus before and one month after transplant; ${ }^{\ddagger} P<0.05$ versus before, and one and three months after transplant; ${ }^{\S} P<0.05$ versus three months after transplant

ter at rest, while sitting on the cycle ergometer and in the final minute of each exercise stage. Mixed expired gases were analyzed continuously during the exercise test. Subjects breathed through a low resistance, high velocity valve (Hans Rudolph) connected on the inspired side to a gas meter and on the expired side to a $4.5 \mathrm{~L}$ mixing chamber. Expired gases were sampled continuously (rate 4 to $6 \mathrm{~L} / \mathrm{min}$ ) and analyzed for oxygen and carbon dioxide content (Ametek). Data were processed on-line by a microcomputer programmed to correct for delays between the signals for volume and gas concentration. Average values for each $15 \mathrm{~s}$ interval were presented for the following variables: respiratory rate, minute ventilation, tidal volume, oxygen uptake, carbon dioxide output and heart rate. The anaerobic threshold was determined noninvasively using the V-slope method (3). Individual slopes of the relationship between minute ventilation and carbon dioxide output below the ventilatory threshold were calculated by linear regression using the least squares' method. Predicted values for maximal oxygen uptake ( $\mathrm{VO}_{2}$ max $)$ were derived using equations, $\dot{\mathrm{V}} \mathrm{O}_{2 \mathrm{max}} / \mathrm{kg}=60-(0.55 \times$ age $)$

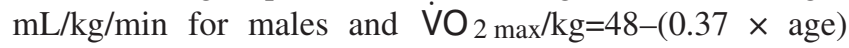
$\mathrm{mL} / \mathrm{kg} / \mathrm{min}$ for females (4).

Resting hemodynamics: Supine resting right heart hemodynamic measurements were performed in all heart failure patients when evaluated for cardiac transplantation. After transplant, supine resting central hemodynamic measurements were repeated during a routine endomyocardial biopsy at one to two weeks and at three and 12 months postsurgery as previously described (5). Briefly, after the endomyocardial biopsy was performed through the right internal jugular vein, a flow directed catheter was introduced and advanced into a branch of the right pulmonary artery for central hemodynamic measurements. Cardiac outputs were measured by thermodilution in duplicate or triplicate to obtain values in agreement by $10 \%$.

Statistical analyses: Values are presented as mean $\pm \mathrm{SD}$. Pre- and post-transplant comparisons of weight and resting hemodynamics were made by ANOVA for repeated measures followed by the Scheffe post hoc test. Because of the limited number of patients exercised before transplant, the exercise values before transplant were compared with the values measured after transplant using an unpaired Student's $t$ test. The exercise test variables measured at one, three and 12 months were compared by ANOVA for repeated measures. To determine the difference between the ventilatory response to carbon dioxide output, the slopes of the regression line were compared as described above. Statistical significance was determined at $\mathrm{P}<0.05$. 

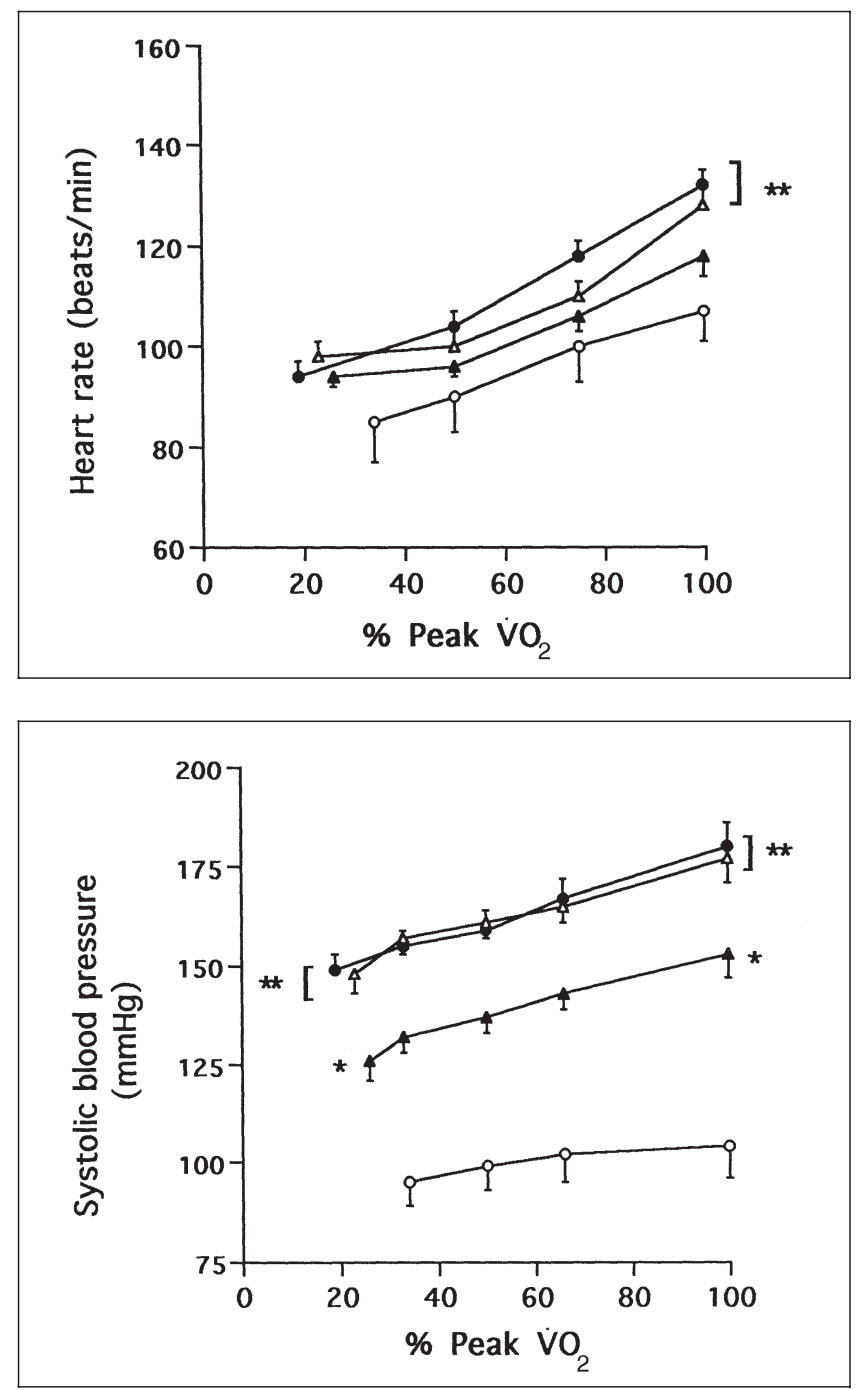

Figure 1) Heart rate (top) and blood pressure (bottom) response as a function of normalized work (percentage of peak oxygen uptake $\left(\mathrm{VO}_{2}\right)$ in patients before $(\bigcirc)$ and at one $(\mathbf{\Delta})$, three $(\triangle)$ and 12 months $(\mathbf{O})$ following cardiac transplantation. Values are mean \pm SEM. *Significantly different from before transplant value $(P<0.05)$; **Significantly different from before and one month post-transplantation $(P<0.05)$

\section{RESULTS}

The supine resting right atrial and pulmonary capillary wedge pressures decreased and the cardiac index increased significantly by one to two weeks after transplantation with no further changes at three and 12 months (Table 1).

In the seven patients who underwent an exercise test before transplantation, 2 max was very low, to a value equal to $29 \%$ of predicted (Table 2). $\dot{\mathrm{VO}}_{2}$ max increased significantly in the first three months after cardiac transplant but did not increase further by 12 months. The ventilatory threshold also increased post-tranplant, but the increase was of a lesser magnitude than the $\mathrm{VO}_{2}$ max so the relative percentage $\mathrm{VO}_{2}$ max at the ventilatory threshold decreased after transplant (Table 2). In the seven patients tested before and after transplantation, the $\dot{\mathrm{VO}}_{2} \max$ and ventilatory threshold increased on average from $9.8 \pm 1.4$ to $18.7 \pm 7.9 \mathrm{~mL} / \mathrm{kg} / \mathrm{min}$,
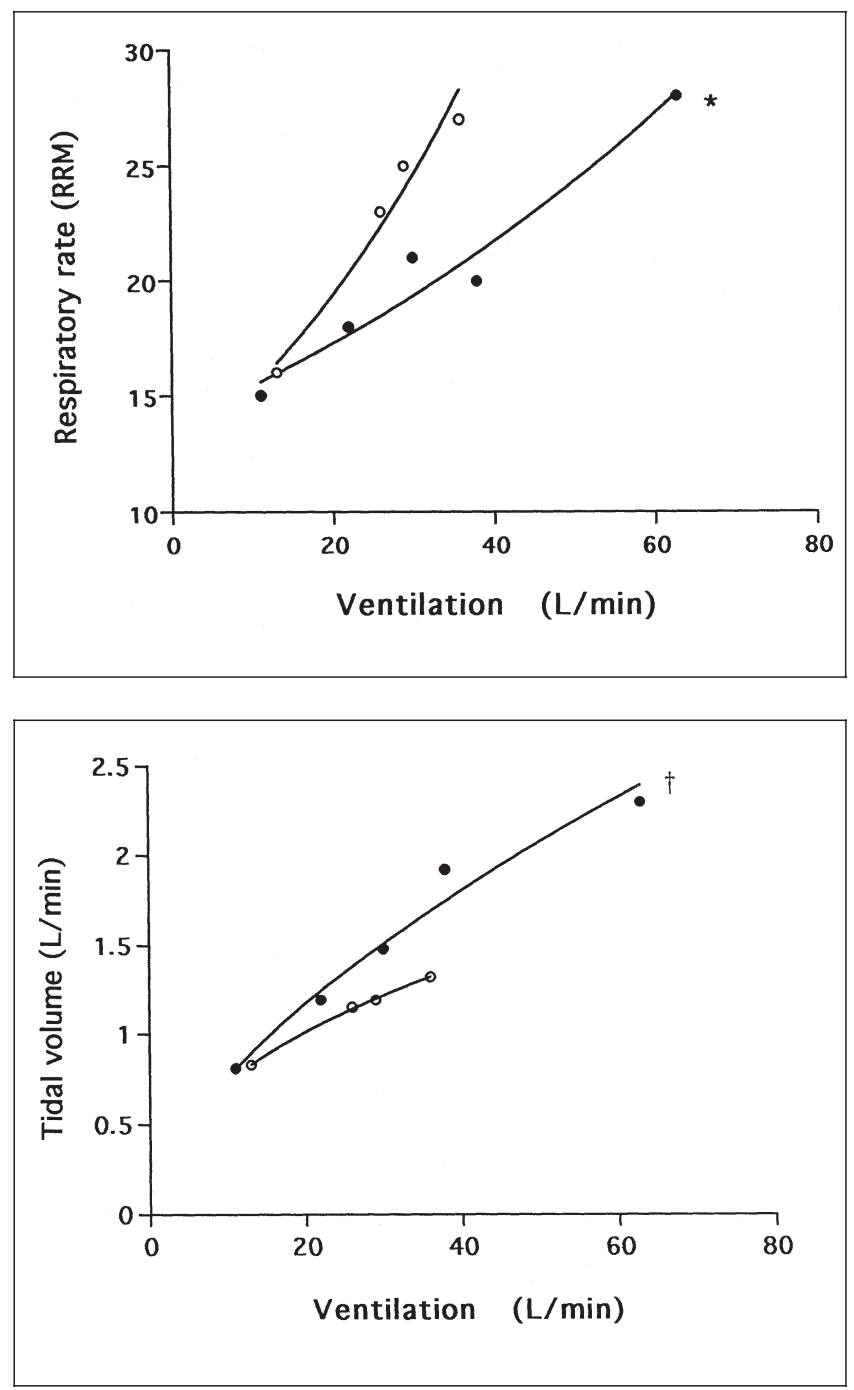

Figure 2) Relationship among ventilation, respiratory rate (top) and tidal volume (bottom) in patients before $(\bigcirc)$ and at 12 months (○) following cardiac transplantation. *Peak ventilation significantly different from pretransplantation $(P<0.05) ;{ }^{\dagger}$ Peak tidal volume significantly different pretransplantation $(P<O .05)$. RRM

$\mathrm{P}<0.02$ and $7.5 \pm 1.5$ to $12.0 \pm 4.3 \mathrm{~mL} / \mathrm{kg} / \mathrm{min}, \mathrm{P}<0.05$ for preand 12-months post-transplant, respectively.

The resting heart rate did not increase significantly after transplant (Table 2, Figure 1). With exercise, a significantly higher peak heart rate was observed at three and 12 months after transplant compared with pretransplant values (Table 2, Figure 1). Resting systolic and diastolic blood pressures were low in the patients before transplant (Table 2). They increased significantly in the first three months after transplant (Table 2). During exercise, heart failure patients had a blunted blood pressure response to exercise (Figure 1). After cardiac transplantation, a greater increase in systolic blood pressure was observed during exercise (Figure 1). At all times, diastolic blood pressure did not change significantly with exercise.

Resting values for minute ventilation, tidal volume and 
respiratory rate did not change after transplantation. Peak minute ventilation, however, was higher following transplantation (Table 2). Because the peak respiratory rate was similar at all times, the rise in minute ventilation after transplantation was due to a higher peak tidal volume (Table 2, Figure 2). Despite lower minute ventilation at peak exercise before transplant, patients had a significantly greater minute ventilation for a given level of carbon dioxide output. The average slope of ventilation to carbon dioxide output $\left(\dot{\mathrm{V}} \mathrm{E} / \dot{\mathrm{V}} \mathrm{CO} \mathrm{O}_{2}\right)$ decreased significantly by three months after transplantation, and an additional decrease was noted at 12 months post-transplant (Table 2, Figure 3).

\section{DISCUSSION}

Patients with heart failure assessed for cardiac transplantation have a marked decrease in exercise capacity and an abnormal cardiopulmonary response to exercise (6). The present study provides some insights into the time course and magnitude of the change in cardiopulmonary response to exercise after cardiac transplantation of patients enrolled in a rehabilitation program in the first three months after transplantation. Increased $\dot{\mathrm{VO}}_{2}$ max was observed as early as one month after transplant, and further improvement was noted by three months. The increase in $\dot{\mathrm{VO}}_{2} \max$ was associated with improvement in the hemodynamics and the ventilatory response to exercise.

At our centre, a rehabilitation program is initiated within the first few days after transplantation and is continued for three months in all patients. It was not possible to organize a matched-control series and, therefore, it is difficult, based on the present results, to dissociate the contribution of the heart from the exercise program in the early improvement of exercise capacity after transplantation. The marked increase in $\mathrm{VO}_{2}$ max of approximately $100 \%$ at three months post-transplant suggests, however, that the new heart plays an important role in the improved exercise capacity of patients during this time because published reports on exercise training in patients with heart failure $(7,8)$ and cardiac transplant recipients $(9,10)$ have observed at best a $15 \%$ to $33 \%$ increase in VंO 2 max. We believe, however, that the early rehabilitation program in our patients may have accelerated the rate of recovery. $\mathrm{VO}_{2}$ max measured in our patients at three months post-transplant was higher than that reported in patients not enrolled in an early rehabilitation program $(11,12)$.

In the present study, despite marked improvement in exercise capacity by 12 months after cardiac transplant, $\dot{\mathrm{VO}}_{2} \max$ remained well below the normal predicted value for age and sex $(59 \%$ of predicted). Impairment in exercise capacity in patients late after cardiac transplantation has been previously observed by us $(13)$ and others $(9,14)$. It is possible that if the supervised rehabilitation program had been extended to beyond three months, a higher peak oxygen uptake might have been observed late post-transplant. Kavanagh et al (9) have reported $\dot{\mathrm{VO}}_{2}$ max approaching normal values in cardiac transplant recipients after a two-year walk/jog intensive exercise program. However, whereas prolonging the rehabilitation program may have increased the $\mathrm{VO}_{2}$ max in some

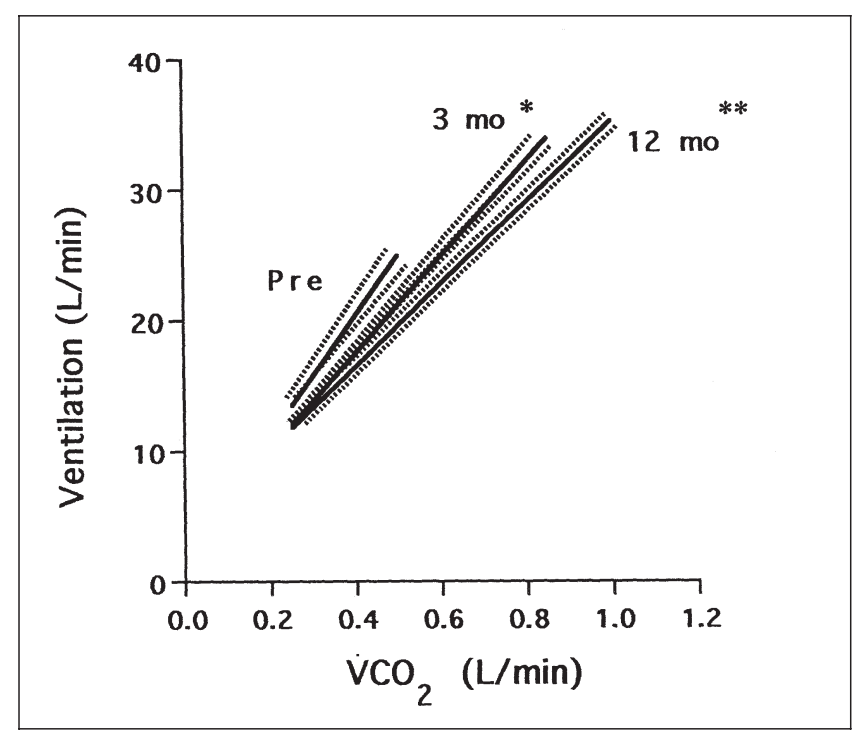

Figure 3) Relationship of ventilation and carbon dioxide output $\left(\mathrm{VO}_{2}\right.$ max) below the ventilatory threshold before and at three and 12 months following cardiac transplantation. Dotted line represents the standard error of the mean slope. *Significantly different from pretransplant $(P<0.05)$; **Significantly different from pre- and three months post-transplant $(P<0.05)$

patients, in many, the long term rehabilitation potential may be limited due to postoperative complications $(15,16)$, use of medications (17) and possibly irreversible peripheral changes from long standing heart failure and inactivity $(13,14)$.

Because $\mathrm{V}_{2}$ max is influenced by patient motivation, we have also measured the ventilatory threshold. The ventilatory threshold is an objective index of aerobic capacity not influenced by motivation, and its determination is reproducible even in heart failure patients $(18,19)$ and heart transplant recipients (20). We have observed an increase in the ventilatory threshold after transplant, confirming that the higher exercise capacity after cardiac transplant was the result of physiological changes, leading to improved oxygen delivery and utilization. The magnitude of the increase in ventilatory threshold, however, was less than the $\dot{\mathrm{VO}}_{2} \max$ so that the relative percentage of $\dot{\mathrm{VO}}_{2}$ max at the ventilatory threshold decreased after transplant (Table 2). The decrease in the relative percentage of $\dot{\mathrm{VO}}_{2}$ max at the ventilatory threshold coupled with the higher peak respiratory exchange ratio at one month after transplant suggest that patients were able to exercise at a higher intensity. This is possibly the result of decreased pulmonary congestion early after cardiac transplant. The persistence, however, of a low relative percentage of $\dot{\mathrm{V}} \mathrm{O}_{2 \text { max }}$ at the ventilatory threshold at three and 12 months post-transplant suggests that these subjects, unlike welltrained athletes, might have only minimal peripheral adaptations after transplant. Limited peripheral adaptations (13) could be due to irreversible changes from prolonged periods of inactivity or changes due to prednisone and cyclosporine therapy. Brubaker et al (20) have observed similar relative percentage of $\dot{\mathrm{VO}}_{2}$ max at the ventilatory threshold in cardiac 
transplant recipients and have confirmed this finding using lactate measurements.

Patients with severe congestive heart failure have an attenuated heart rate and blood pressure response during exercise compared with healthy control subjects (21). This is, in part, the result of a diminished sympathetic nervous system response to exercise (22) and reduced density of beta-adrenergic receptors in the failing myocardium (23). In this study, our patients exhibited blunted heart rate and systolic blood pressure responses to exercise before transplant. After transplant, a significant increase in peak heart rate was observed; however, the peak heart rate remained below the age-adjusted maximal predicted heart rate of 174 beats/min (4) because of a lack of direct sympathetic stimulation from cardiac denervation (24,25). Marked increases in resting and peak blood pressures were also observed after cardiac transplant. The early increase in blood pressure is due to improved cardiac function. Thereafter, the resting blood pressure continues to increase in most patients, possibly due to denervation and/or the hypertensive effect of cyclosporine therapy (17). In our study more than $70 \%$ of patients at 12 months post-transplant required antihypertensive medication to normalize their blood pressure.

In addition to abnormal hemodynamics response to exercise, patients with severe heart failure had abnormal ventilatory response. Weber et al (21) have reported lower peak ventilation with an augmented ventilatory response in patients with severe congestive heart failure compared with less impaired patients or controls. Results from the present study agree with those findings. Furthermore, the present study illustrates that abnormal ventilatory response to exercise is, like the resting pulmonary function (26), in part reversible after cardiac transplant. After cardiac transplant, we have observed a higher ventilation and tidal volume at peak exercise, possibly the result of increased lung compliance and blood supply to the respiratory muscles during exercise. While patients before transplant had a high ventilation for a given carbon dioxide production, the slope of the relationship during submaximal exercise decreased and continued to decrease for up to 12 months. The pathophysiological basis for the augmented ventilatory response during exercise in heart failure patients is not fully understood $(8,21,27)$. Numerous underlying mechanisms have been suggested including early onset of systemic and skeletal muscle acidosis (2,21), ergoreceptor activation (28), increased dead space to tidal volume ration from lung congestion and change in lung compliance $(8,29)$, increased pulmonary capillary wedge pressure (27) and increased ventilation/perfusion mismatch $(8,30)$, all of which could improve after transplantation. Despite a marked decrease in the slope of the ventilation to carbon dioxide output relationship after transplant, the slope did not return to the reported normal value of approximately 23 (31). Coexisting pulmonary diseases from previous smoking, permanent lung changes from long-standing pulmonary venous hypertension and/or the possible effect of cyclosporine on the pulmonary vasculature (32) may all have contributed to this finding (33).

One limitation of the present study is that fewer than half of the patients studied underwent exercise testing before transplantation. We believe, however, that the exercise capacity of the patients tested is representative of the remaining patients. It may even overestimate it because most of the patients were too sick to exercise.

In summary, exercise capacity improved markedly after cardiac transplant. The increase in exercise performance is associated with changes in both respiratory and cardiovascular response to exercise. A rehabilitation program in the first three months after cardiac transplant may accelerate the rate of recovery in patients without normalizing the exercise capacity late post-transplant. Despite marked improvement in exercise capacity, the $\mathrm{VO}_{2}$ max of recipients 12 months after cardiac transplant remained low, at less than two-thirds of the predicted value.

\section{REFERENCES}

1. Pennock JL, Oyer PE, Reitz BA, et al. Cardiac transplantation in perspective for the future. J Thorac Cardiovasc Surg 1982;83:168-77.

2. Franciosa JA, Leddy CL, Wilen M, Schwartz DE. Relation between hemodynamic and ventilatory responses in determining exercise capacity in severe congestive heart failure. Am J Cardiol 1984;53:127-34.

3. Beaver WL, Wasserman K, Whipp BJ. A new method for detecting anaerobic threshold by gas exchange. J Appl Physiol 1986;60:2020-7.

4. Jones NL. Clinical Exercise Testing. Toronto: WB Saunders Co, 1988.

5. Pflugfelder PW, McKenzie FN, Kostuk WJ. Hemodynamic profiles at rest and during supine exercise after orthotopic cardiac transplantation. Am J Cardiol 1988;61:1328-33.

6. Mancini DM, Ersen H, Kussmaul W, Mull R, Edmunds LH, Wilson JR. Value of peak exercise oxygen consumption for optimal timing of cardiac transplantation in ambulatory patients with heart failure. Circulation 1991;83:778-86.

7. Coats AJS, Adamopoulos S, Radaelli A, et al. Controlled trial of physical training in chronic heart failure. Circulation 1992;85:2119-31.

8. Sullivan MJ, Higginbotham MB, Cobb FR. Increased exercise ventilation in patients with chronic heart failure: intact ventilatory control despite hemodynamic and pulmonary abnormalities. Circulation 1988;77:552-9.

9. Kavanagh T, Yacoub MH, Mertens DJ, Kennedy J, Campbell RB,

Sawyer P. Cardiorespiratory responses to exercise training after orthotopic cardiac transplantation. Circulation 1988;77:162-71.

10. Keteyian S, Ehrman J, Fedel F, Rhoads K. Heart-rate perceived exertion relationship during exercise in orthotopic heart transplant patients. J Cardiopulmonary Rehabil 1990;10:287-93.

11. Mandak JS, Aaronson KD, Mancini DM. Serial assessment of exercise capacity after heart transplantation. J Heart Lung Transplant 1995; $14: 468-78$.

12. Ehrman J, Keteyian S, Fedel F, Rhoads K, Levine TB, Shepard R. Cardiovascular responses of heart transplant recipients to graded exercise testing. J Appl Physiol 1992;73:260-4.

13. Bussières LM, PW Pflugfelder, McKenzie FN, et al. Basis for aerobic impairment in patients after heart transplantation. J Heart Lung Transplant 1995;14:1073-80.

14. Savin WM, Haskell WL, Schroeder JS, Stinson EB. Cardiorespiratory responses of cardiac transplant patients to graded, symptoms-limited exercise. Circulation 1990;62:55-60.

15. Hosenpud JD, Morton MJ, Wilson RA, et al. Abnormal exercise hemodynamics in cardiac allograft recipients 1 year after cardiac transplantation. Circulation 1989;80:525-32.

16. Labovitz AJ, Drimmer AM, McBride LR, Pennington DG, Willman VL, Miller LW. Exercise capacity during the first year after cardiac transplantation. Am J Cardiol 1989;64:642-5.

17. Scherrer U, Vissing SF, Morgan BJ, et al. Cyclosporine-induced 
sympathetic activation and hypertension after heart transplantation. N Engl J Med 1990;323:693-9.

18. Itoh H, Taniguchi K, Koike A, Dot M. Evaluation of severity of heart failure using ventilatory gas analysis. Circulation 1990;81(Suppl 2):31-7.

19. Weber KT, Janicki JS. Cardiopulmonary exercise testing for evaluation of chronic cardiac failure. Am J Cardiol 1985;55:22A-31A.

20. Brubaker PH, Berry MJ, Brozena SC, et al. Relationship of lactate and ventilatory thresholds in cardiac transplant patients. Med Sci Sports Exerc 1993;25:191-6.

21. Weber KT, Kinasewitz GT, Janicki JS, Fishman AP. Oxygen utilization and ventilation during exercise in patients with chronic cardiac failure. Circulation 1982;65:1213-2.

22. Francis GS, Goldsmith SR, Zicsche S, Nakajima H, Cohn JN. Relative attenuation of sympathetic drive during exercise in patients with congestive heart failure. J Am Coll Cardiol 1985;5:832-9.

23. Bristow MR, Ginsburg R, Minobe W, et al. Decreased catecholamine sensitivity and beta-adrenergic-receptor density in failing human hearts. N Engl J Med 1982;307:205-11.

24. Quigg RJ, Rocco MB, Gauthicr DF, Creager MA, Hartley LH, Colucci WS. Mechanism of the attenuated peak heart rate response to exercise after orthotopic cardiac transplantation. J Am Coll Cardiol 1989;14:338-44.

25. Pope SE, Stinson EB, Daughters GT, Schroeder JS, Ingels NB,
Alderman EL. Exercise response of the denervated heart in long-term cardiac transplant recipients. Am J Cardiol 1980;46:213-8.

26. Bussières LM, Pflugfelder PW, Ahmad D, Taylor AW, Kostuk WJ. Evolution of resting lung function in the first year after cardiac transplantation. Eur Respir J 1995;8:959-62.

27. Gazetopoulous M, Davies H, Oliver C, Deuchar D. Ventilation and haemodynamics in heart disease. Br Heart J 1966;28:1-15.

28. Piepoli M, Clark AL, Volterrani M, Adamopoulos S, Sleight P, Coats AJS. MContribution of muscle afferents to the hemodynamics, autonomic and ventilatory responses to excerise in patients with chronic heart failure. Circulation 1996;93:940-52.

29. Clark AL, Poole-Wilson PA, Coats AJ. Relation between ventilation and carbon dioxide production in patients with chronic heart failure. J Am Coll Cardiol 1992;20:1326-32.

30. Myers J, Salleh A, Buchanan N, et al. Ventilatory mechanisms of exercise intolerance in chronic heart failure. Am Heart J 1992;124:710-9.

31. Rebuck A, Jones NJ, Campbell EJM. Ventilatory response to exercise and to $\mathrm{CO}_{2}$ rebreathing in normal subjects. Clin Sci 1972;43:861-7.

32. Casan P, Sanchis J, Cladellas M, Amengual MJ, Caralps JM. Diffusing lung capacity and cyclosporine in paticnts with heart transplant. J Heart Lung Transplant 1987;6:54-6.

33. Marzo KP, Wilson JR, Mancini DM. Effects of cardiac transplantation on the ventilatory response to exercise. Am J Cardiol 1992;69:547-53. 


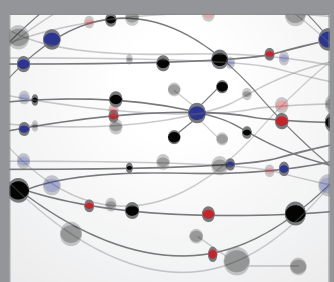

The Scientific World Journal
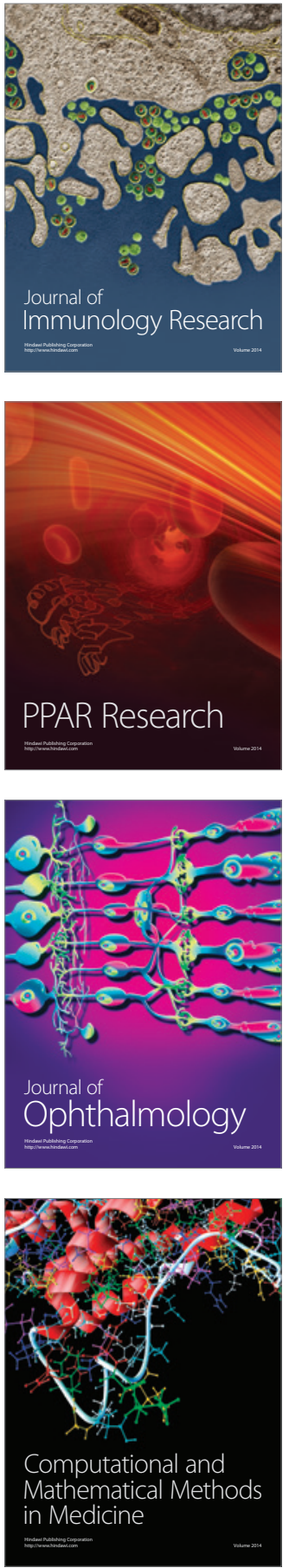

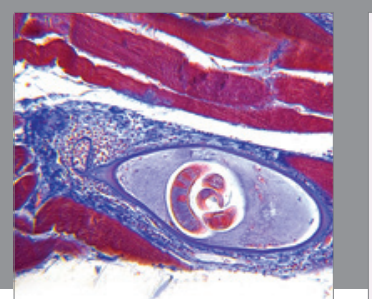

Gastroenterology Research and Practice

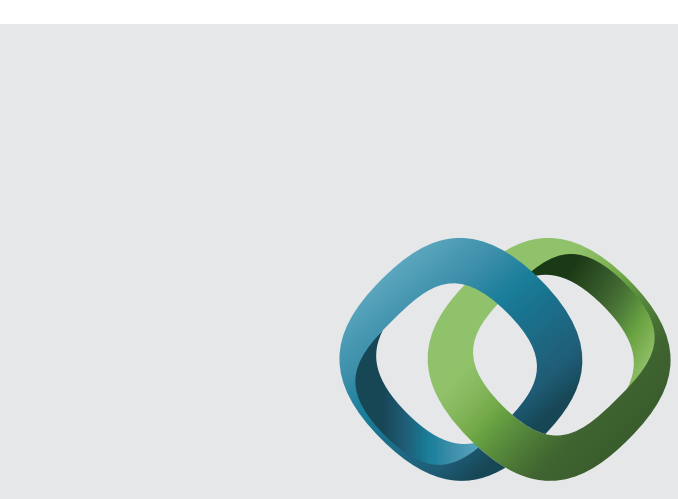

\section{Hindawi}

Submit your manuscripts at

http://www.hindawi.com
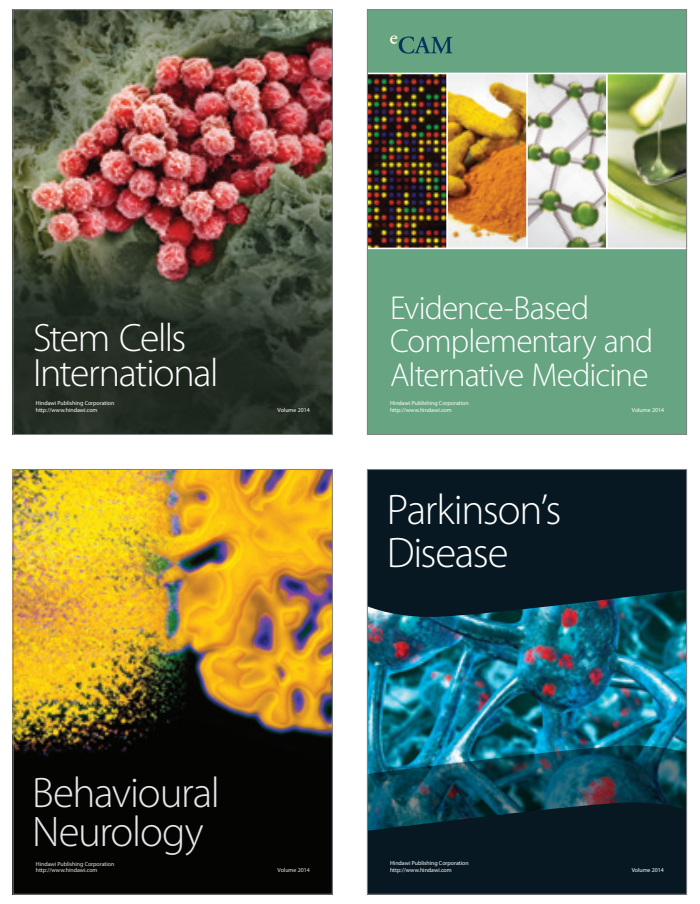
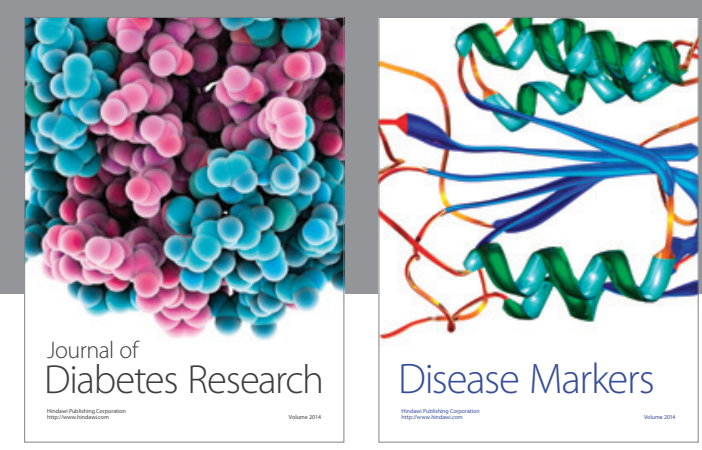

Disease Markers
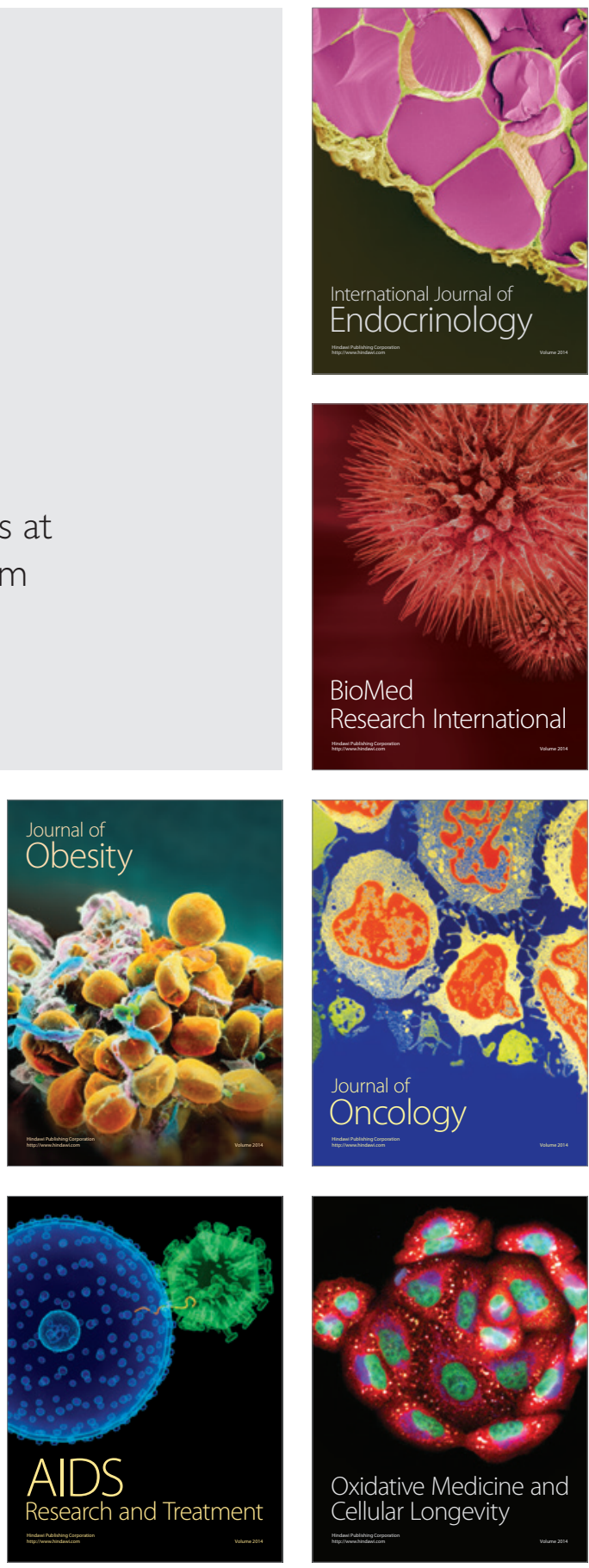